\title{
Ирина Коваль-Фучило
}

Институт искусствоведения, фольклористики и этнологии имени Максима Рыльского НАН Украины (Киев)

koval-fuchylo@ukr.net

ORCID: oooo-0003-4048-9114

\section{Темы-табу и темы-фавориты \\ в воспоминаниях о принудительном переселении}

\section{The favorite and the taboo in memories concerning forced resettlement}

DOI: $10.12775 /$ LL.4.2021.002 | CC BY-ND 4.0

\begin{abstract}
The article is devoted to the analysis of the favorite (popular) and the taboo (rarely verbalized) themes and motives in memories concerning forced relocation from flood zones resulting from the construction of hydroelectric power plants in Ukraine. Common topics include the idealization of the forsaken place, stories about helping one another, the emphasis on the loss of home, land, community, graves and cemeteries, as well as descriptions of meetings of migrants from the same. Unpopular topics concern the resettlement achievements as well as the migrants' priorities and new opportunities. The topic selection is influenced by the chosen strategy of self-presentation, the narrator's personal experience, and current moods in society as well as in the local community. The assessment of resettlement also depends on the respondents age. That event appears to have been the most difficult for people who were middle-aged and older at the time, who were actually forced to demolish their houses and build new ones in a new place, and become accustomed to new conditions. In the stories of people who were children during the resettlement, the emphasis is somewhat shifted towards stories about meetings former villagers, reflections on the meaning of erecting hydroelectric power plants and the ensuing ecological aftermath. The material analyzed in the article constitutes oral recollections of forced migration, recorded during 2012-2019 in places of mass resettlement from flooded villages.
\end{abstract}

KEYWORDS: memory narratives, migrations, forced resettlement, Ukraine 
С конца І920-х годов и вплоть до начала І980-х годов в Украине происходило строительство гидроэлектростанций. Были возведены шесть ГЭС на Днепре и одна на Днестре. В результате сооружения этих мегаобъектов было осуществлено принудительное переселение людей из территорий, отведенных под затопление. Долгое время это строительство оценивалось только положительно, согласно с советской пропагандой о „выходе людей из болот”, „освоении Днепра”, „строительстве моря”, „электрификации всей страны”. О природных и культурных потерях никто не говорил. Переосмысление достижений и потерь вследствие строительства ГЭС началось в начале 2000-х годов и продолжается до сих пор.

На сегодня исследованы этапы и стратегия трансформации украинского Приднепровья в результате гидроэнергетического освоения Днепра (Горбовий 2015, $2016,2020)$, усилиями энтузиастов написаны и опубликованы книги о затопленных селах (Горбняк 2004, 20I8, 2020; Кузьменко-Лісовенко 20I8; Лесик 2007; Михняк 20I8, 2020; Михняк, Зубер 20I9; Сорокова 20I5), энтузиасты стремятся создать музей исчезнувших сел на Переяславщине (Іващенко 20I7). Целью моих научных интересов является сбор и анализ устных воспоминаний о принудительном переселении из зоны затопления, исследование современных форм сохранения памяти о затопленных селах в контексте изучения мемориальной культуры в Украине и Европе.

Задача предлагаемого исследования - определить и проанализировать любимые и табуированные темы в воспоминаниях о принудительных переселениях, то есть выяснить, какие темы, сюжеты, мотивы популярны, о чем рассказывают много и с удовольствием, а о чем рассказывают неохотно или вообще молчат. Основной базовый материал моих исследований -записи интервью с переселенцами, а также с людьми, судьба которых была связана с переселением. Эти записи были сделаны во время экспедиционной полевой работы в течение 20I2-20I9 годов. Места записи указаны в перечне информантов.

В работе использованы общие (наблюдение, сравнение) и специальные (интервьюирование, сравнительно-исторический, структурный текстовый анализ) методы исследования.

Существование любимых и табуированных тем, сюжетов, мотивов исследователи устной истории обнаружили на разном материале. Для нас важны наблюдения ученых, основным предметом внимания которых были принудительные переселения. В 2015 г. было опубликованоисследование Беаты Галицкой Polski Dziki Zachód. Przymusowe migracje i kulturowe oswajanie Nadodrza 1945-I948 (Польский дикий запад. Принудительные миграции и культурное освоение Надодрщины I945-I948) (Halicka 20I5). В этой книге автор поднимает проблему заселения и особенностей адаптации пространства так называемых „возвращенных земель” (польск. Ziemie Odzyskane). Это бывшая территория Третьего рейха, которая была передана Польше по условиям двух международных конференций I945 г. - Ялтинской и Потсдамской. Исследование Беаты Галицкой можно назвать попыткой международного взгляда на проблему принудительных миграций в послевоенной Европе, подходом к пониманию этого явления как общеевропейского. Среди источников предлагаемого исследования - воспоминания 
переселенных лиц; работа написана в контексте так называемой „истории второй степени”, когда речь идет не просто о событиях, а об „истории памяти об этих событиях" (Halicka 20I5: 44). Исследовательница выделяет два вида тем -запрещенные цензурой темы и автотабуированные темы. Так, не разрешено было критиковать экспансивную политику Советского Союза в конце Второй мировой войны или смещение Польского Государства на запад. „Не допускались также описания советской оккупации на Крессах, процесс коллективизации, а также этнические конфликты. Разрешены были только упоминания об украинских »партизанских бандах«, которые трактовали как врагов польского населения и коммунистического режима" (Halicka 20I5: I6I). Запрещенными были грусть по утраченной родине, чувство отчужденности. Нельзя было также критиковать коллективизацию, введенную советской властью в этом регионе.

Типичным, излюбленным мотивом воспоминаний поляков-мигрантов является стремление подчеркнуть исключительность собственной судьбы, акцентировать свои заслуги как пионера, первопроходца, первопоселенца на так называемом польском „диком западе”. Еще одним таким мотивом является идеализация потерянного места. Рассказчики сознательно или бессознательно не описывают негативных моментов на потерянном, утраченном месте. В то же время они редко задумываются о том, какие положительные изменения произошли в их жизни благодаря перемене места жительства. Среди любимых мотивов - описание общественных работ. Люди хорошо помнят и с удовольствием рассказывают о совместных работах, о взаимопомощи, совместных достижениях в быту и культурной жизни. Коллективный труд, прожитое вместе время оставляют после себя положительные эмоции, которые хранятся в коллективной памяти долгие годы. Табуированным мотивом является присвоение имущества немцев, живших на „возвращенных землях”; кроме этого, в воспоминаниях поляков-переселенцев совсем мало внимания посвящено изгнанию немцев. В то же время это событие является ведущей темой в мемуарах немецких переселенцев. „Колонна беглецов на фоне зимнего пейзажа является символом беженства и изгнания в Европе XX века. К наиболее драматическим событиям в истории немецких изгнаний принадлежит, несомненно, бегство замерзшим Балтийским морем в январе I945 года" (Halicka 20I5: I04). Табуированы также темы послевоенного польского антисемитизма и принудительного переселения украинцев с этнических территорий.

Еще одно важное исследование - работа о беженцах Первой мировой войны: Bieżeństwo 1915. Zapomniani uchodźcy (Prymaka-Oniszk 20I7). Распространенными мотивами воспоминаний о времени беженства является внимание к хлебу как одному из важнейших видов пищи крестьян, жизненной ценности, „дара Божьего”, символа благополучия и плодовитости. Концепт хлеба вербализирован в воспоминаниях о вынужденном бегстве вследствие сожженных полей и ограбленных зернохранилищ, в размышлениях о запахе хлеба, назначении черного и белого хлеба, в рассказах об уничтожении большевиками готового зерна в реках. Среди распространенных мотивов - уже упомянутая идеализация потерянного края. Никто не вспоминает ни об испытаниях, ни о неудачах, ни о пережитых когда-то обидах. 
Автор выделяет табуированные в рассказах темы. Так, многим беженцам удалось довольно неплохо устроиться на новом месте. Они получали государственную помощь деньгами и продуктами. Кое-где это была также ценная в то время одежда и обувь. Часто эта помощь была выше, чем доходы людей, которые приютили беженцев. Беженцам не приходилось работать. Это провоцировало недовольство среди местных жителей и привело к возникновению лени среди принудительных мигрантов. В то же время упоминаний об этом нет в воспоминаниях о беженстве (Prymaka-Oniszk 20I7: I82). Известны также случаи, когда беженцы становились жертвами нечестных работодателей и долгое время работали без оплаты. Об этом также не часто вспоминают. „Преобладает гармоничный образ общей с местными жителями жизни и совместной работы” (Prymaka-Oniszk 20I7: I82). Еще одной табуированной темой являются психические болезни беженцев, вызванные травмой потери целого былого мира, травмой ужасного переезда, невосполнимых потерь. Вытеснены из воспоминаний также упоминания о беспомощности, бессилии, безнадежности, злости, отчаянии. Это все не подходит к образу беженцев, который рассказчики представляют в своих воспоминаниях. Ведущей в рассказах о беженстве является идея потери. Именно поэтому никто не думает о его плюсах, о полученном опыте. Так, например, в воспоминаниях никто не говорит о том, что люди стали открытыми к новому, отважными, готовыми воспринимать ранее неизвестное. В других условиях постижение этого продолжалось бы, пожалуй, несколько поколений.

Факты непохороненных в дороге умерших родственников - это также достаточно табуирована тема в семьях беженцев. Трудно объяснить потомкам все особенности пути побега от войны, чтобы оправдать это. Но чаще умерших все же хоронят, причем стараются сохранить как можно больше составляющих своего локального погребального обряда.

Упомянутые работы, а также другие важные исследования принудительных переселений (Wylegała 20I4; Godyń 20I5) помогли мне в научных поисках. Среди фольклористических подходов польских ученых мне наиболее близко понимание устной истории как способа понимания прошлого в работах Янины ГайдукНияковской (Hajduk-Nijakowska 2020: 45).

Источники устной истории о принудительных переселениях из зон затопления дают основания выделить такие теми-фавориты в воспоминаниях переселенцев:

- идеализация потерянного места и общества;

- акцент на потере земли как важного средства существования;

- разрушение родного дома и сосредоточенное внимание на строительстве нового жилья;

- коллективный труд и совместно прожитые дни с другими участниками события, взаимопомощь;

- перенос, потеря могил, кладбищ;

- сравнение масштабов своей трагедии с другими, часто худшими историческими событиями;

- рассказы о встречах переселенцев одного села в наше время. 
Основные табуированные и непопулярные темы:

- достижения в результате переселения;

- преимущества переселенцев по сравнению с другими жителям;

- недооценка полученного опыта.

Проанализируем перечисленные пункты.

Идеализация поте рянного ме ста - это loci communes вcex воспоминаний о принудительных переселениях. Покинутое, потерянное место в рассказах приобретает идеальные черты, образ утраченного рая. Идеализация чаще всего проявляется в описаниях красивых пейзажей, богатых природных ресурсов, успешного хозяйствования, особенно дружной общины, а также в сознательном, а чаще неосознанном умолчании или преуменьшении негативных воспоминаний, связанных с потерянным местом. Усилению идеализации способствует использование бинарной оппозиции, на полюсах которой расположены две локации - потерянное село и вынужденное место поселения (КовальФучило 2020b). Часто такая конструкция - это поэтическая картина утраченного пейзажа в противовес участку, который люди получили на месте поселения:

Там у нас був дуже город гарний. Там у нас було клубники багато, город великий, сінокіс для корови був свій. І таке ж було деревце коє-яке було: то сливи, то груші. Отаке було. Тоді багато у нас садів там не було, де посадки взять, шоб його посадить. А так усе дуже гарно родило. Був і низ, був і бугор там. Все ми своє вирощували, і були довольні, бо там усе було (ЧЕА)․

Ну, мені там лучше було. Я там привикла. Гарно там було. А тута шо? Бачите, нема ніде нічого (ЮНС).

Там в нас гарно було на хуторку тоже: гора, а внизу ліс був вільховий, зелено було тоже, садки були у всіх [...]. А там в нас гарно було: гора, тут і ліс ізнизу (ОЕП).

А там таке воно: дерева, тепло, трави. Дуже гарно було. Багатьом воно так сниться [...]. До води, до низу, до лужка хочеться. І хоч тут така земля, такий чорнозем, а води нема (ЗВФ).

Лучшей на родном месте была не только земля, а вода и даже воздух: „Мені 62 чи скільки, то мені там лучче було, як отуто. Там воно просто було, понімаєте, ну як вам сказать- луг там. I наче мені й воздух не такий” (ЮНС).

Типичная черта описания утраченного села - многочисленные микротопонимы, которые свидетельствуют об обжитости, освоенности территории: „Ми знаєм кожен той ярочок, де це ті хати наші: Прокопів ярок, Жидівский ярок, Рипа, там місток був, і то Згониво - там худобу зганяли. Панський ярок - тутво близько

I Здесь и далее аббревиатурой обозначено имя рассказчика, приведенное в перечне информантов в конце статьи. 
в селі” (ЛФЛ). Такое разнообразие номинации не встречается в описаниях новых поселений, в этих фрагментах почти нет микротопонимов. Вместо этого появляются названия с семантикой необжитости, неупорядоченности: „величезне нічиє поле”, „участки”, „приділена земля”.

Лучше на утраченном месте были не только природа и угодья, но и сельская община:

I село було дуже дружне. [...] А тоді вже оце так сучасні більш, то почали - хтось приїжджать, хтось переїжджать, то хтось приїхав, то хтось оселився, то побачив, шо дуже гарне село, будинки були колгоспні, колгосп почав будувати [...] і почали з'їжджатись. I армяни приїжджали, і росіяни, бо бачили, що гарне село. Колесо оглядове - наче у городі, будинки чотирьохповерхові були. Вони і зараз $\epsilon$, що живуть у квартирах. Тоді вже трошки люди недружні стали. А іменно у [І9]50-х роках, як ще не було переселення, то люди дружні були, одне одному помагали (ЗВФ).

Нам то добре було на низу жити. Село маленьке, дуже дружні люди, ніяких, ніякого нічого в нас там не було (ЛФЛ).

Косвенной формой идеализации утраченного рая является постоянное декларирование готовности переселиться обратно на затопленное пространство, как только с него спустят воду: „От і зара кажуть: а, шоб спустили воду - ми б поїхали б туди. Там виногради були такі, всьо" (НАГ).

Акцент на поте р е з м ли как важного средства существования в воспоминаниях переселенцев из зон затопления зачастую вербализируется в описаниях старого и нового мест проживания (см. об этом: Коваль-Фучило 2020а). Новое место всегда проигрывает старому, хуже оказываются и качество почвы, и расположение, и среда в целом: „Це був колись садок. I тут поле мочеристе” (ЯКИ); „А земля орна була в степах. Людей виселили вверх, де до води не докопати” (ЖНИ); „І вас переселяють просто в чисте поле: ні води, ні доріг. Оце Ленінське, Придніпровське [...]. Нема нічого - чисто голе поле” (КЛГ); „Дуже добра земля, всьо родило, і садки мали, і ... ну, було: і картошка родила, і буряк” (ЯКИ); „Там земля краща. Казали: золота долина” (РНА). Часто основной проблемой становится отсутствие воды: „І хоч тут така земля, такий чорнозем, а води нема" (ЮНС).

Отсутствие воды на вынужденном месте проживания - проблема не только сельскохозяйственная, то есть такая, что препятствует обработке земли, но и бытовая и даже мировоззренческая. Людей, которые веками жили на берегу реки, где вода определяла способ хозяйствования и особенности традиционной культуры, переселяли в засушливые места, часто с принципиально иным типом хозяйствования. В этом контексте закономерны реплики о неподготовленности нового места, о продолжительности и сложности переходного этапа: „Це тільки школа, це [І9]62-ий рік, почала будуваться. А ні парку, нічого. Тут на цих фотографіях нічого ще немає. Поля і все, поля були” (ЗВФ). Интересно, что здесь 
появляется идиома чистое поле в значении „опасное неосвоенное место” (см. об этом: Шевчук 2009: 206-2II).

Потерю плодородных земель в результате затопления многие рассказчики считают самой тяжелой потерей. Вот ответы на мой вопрос „А как вы считаете, больше пользы или больше вреда принесло затопление?”:

Шкоди більше. Такі землі затопить! Дуже шкода. Хай те Васюгання, шо казали, там вічна мерзлота, хай би оте затопляли, а такі землі - поспішили. Поспішили, бо було на ура: „Дайош електрику, п’ятирічки!” I на Дніпрі, Придніпров’я - шість електростанцій потужних! Це ж багато дуже. Дуже багаті землі (ЧМЛ).

Там, де зараз Кременчуцьке водосховище, були найбагатші землі (ЮАЯ).

Семантикой необратимой потери обозначены также воспоминания переселенцев-поляков из зон затопления (Godyń 20I5: 55-77).

Разрушение родного дома и обостренное внимание на ст роительств е нового жи лья - ведущие темы автобиографических воспоминаний о переселении. По сути, основным событием переселения как личного жизненного события была задача разрушить хату и построить новый дом на положенном месте. Рассказы женщин часто сосредоточены именно вокруг этих двух событий: „Люди, канєшно, душевно переживали: хата стоїть, усе гарне - розбий, розрівняй, розвали і зрівняй із долівкою. Тоді прийде комісія - прийме. Нашу хату оцінили в I2 тисяч. Ну, якби оце січас І2 тисяч. Тоді такі гроші були, як січас" (КАФ).

В воспоминаниях переселенцы описывают прощание с домом. Мне даже удалось зафиксировать причитания по дому:

А ви чули, щзоб, може, хтось тужив за хатою?

Та таких текстів було! Вопше! Обнімали всі вугли і цілували. I казали, шо... Та вопше там такий крик був:

Хатка моя рідненька!

Я ж тебе мазала,

Я ж тебе строїла після війни,

А тепер я тебе кидаю!

Я не можу!..

То було, можна сказати, як похорон: люди прощуалися зі своєю територією?

Та... Ой! Ви не представляєте, яка це біль! Тягло яке було, шо ми не могли успокоїться! Вопше! Страшне дєло - пересилка (МАФ)².

2 Важно отметить, что это не единственный случай в украинской причитальной традиции; см. также причитания по дому переселенцев из Винницкой области на Зеленый Клин (КовальФучило 20I2: 676-677). 
Сюжет прощания с домом типичен и для украинских переселенцев из Холмщины: „Мати стала серед подвір’я лицем до хати i, охопивши руками голову, гірко-гірко вголос заридала. А потім ще раз побігла до хати і заголосила, прощаючись 3 рідною оселею. Вона поцілувала ікону, яку залишила берегти хату, а потім ще стіни, одвірки, поріг” (Гук І997: II5). О ритуализированном характере этого прощания свидетельствуют окказиональные плачи, специальные прощальные действия, например, целование углов дома, а особенно само описание, упоминание об этом моменте в воспоминаниях, то есть его вербализация, осмысление носителями традиции (подробно см. об этом: Коваль-Фучило 20г6). Наличие этого момента в нарративах о переселении обусловлено общеславянскими верованиями и представлениями, связанными с домом как одним из центральных концептов в мифопоэтической картине мира.

Среди переселенцев до сих пор бытует традиция или привычка ходить на берег водохранилища и определять, где раньше было расположено родное село, дом: „І от використовуючи чи там неділю, чи якесь свято, люди йшли на берег подивитися на воду, порівняти, яке воно було” (ГТВ); „А зараз вийду на убіч то лиш видю, помню, де була хата. Там вода!” (ДМС); „3 моєї хати лишився підмурок, ми його не брали, високий такий, і площадка така, ми мали веранду робити, площадка. І спаде вода, і то всьо лишається. I то всьо видно. Прийдем подивимся, я кажу: »Боже, подивися«, - до чоловіка. Він каже: »Ходи подивимся на своє місце«" (ЛПА).

Вынужденное строительство нового дома было едва ли не самой трудной задачей переселенцев, о котором они обязательно вспоминают во время интервью: „Та було важко! Вопше, пересилка! Єлє стяглись на ту хату, ми ж ії тільки построїли, раз два помазали, а не білили хату” (ЮНС); „Тоді мати молода була, тоді тіфом боліли, тоже не можна було жить, а хату треба було тут строїть" (ОЕП). Тяжелее всего пришлось людям, которые уже успели после войны построить новый дом. Такие переселенцы чувствовали себя более обиженными, поскольку им, по сравнению с людьми, у которых была старая хата, давали гораздо меньше денег на новый дом. Объясняли это так: можно разобрать старый дом и использовать эти материалы для нового. На самом деле из этого материала на новом месте можно было построить разве что какое-то хозяйственное помещение:

Після війни дід Петро, ii батько, там хатку таку зліпив. Ми там прожили го год. А тут пересилка началась. Оп’ять треба ламать. Тут комісія приїхала: „Так в вас же хата нова, вам за хату треба гроші” 3 [І9]47-го року. 5400 дали. А шо ти за ті гроші построїш? (БВИ).

Трагедию разрушения старого дома особенно рельефно передал в своих художественных произведениях украинский писатель, кинорежиссер, классик мирового кинематографа Александр Довженко (Коваль-Фучило 2020а). Писатель тщательно прорабатывал сцены оплакивания дома, его разрушения. Эти причитания близки с народными текстами. Авторским, а не народным, является текст плача по птичьему гнезду. В то же время, о неслучайности этого сюжета свиде- 
тельствует название книги Софии Сороковой Не летят ласточки в Зарубинцьь (Сорокова 20I5). Таким образом, тема потери жилья и людьми, и птицами была осмыслена и вербализована в переселенческих нарративах.

Тексты устных воспоминаний переселенцев свидетельствуют, что люди не могли смириться с ситуацией, когда дом потерял свое основное предназначение - быть защитой для человека, когда дом обесценился, претерпел разрушение. Доказательствами ситуации неприятия факта разрушения дома служат такие устойчивые конструкции в текстах воспоминаний: „прийшли/зайшли до хати” (в этом высказывании сконцентрирована семантика незаконного проникновения на чужое личное пространство, предчувствие беды, это сигнал будущих трагических событий), „взяли з хати” (рассказчиков не перестают поражать случаи насилия над хозяином дома и его жителями), „убитий коло своєї хати” (даже через десятки лет традиционное сознание поражает факт гибели у родного дома, который должен быть оберегом и защитой для человека, такие случаи обязательно отмечают в воспоминаниях).

Кол ле к т и в ны й т руд и совместно прожитые дни с другими участниками события, в з а и м о п м о ъ - еще один излюбленный мотив воспоминаний переселенцев. Люди рассказывают, как помогали другим строить дома и как помогали им:

Будівництво тоді було в селі не так, як зараз будується, що по три шкури деруть, а тоді було все на толоку'. Зійшлися, приміщення робили, сохи складали і криша. А мазать - толока (МИЛ).

Ну, тоді робили все на толоку’. Тоді люди одне одному помагали (ЗВФ).

Як тут люди будувались? Кожен сам окремо не будувався, а тому що для одного це було не реально. Гуртувалися. Наприклад, на цій вулиці - толокою. Збиралися. Той, наприклад, сьогодні привіз цеглу - збіглися всі, розгрузили. Поки він готує то всьо, що треба - іншому розгрузили. Чи приїжджали, чи приходили. Казали: „Ось сьогодні цьому Андрієві маєм будувати хату”. Звичайно, він забезпечив. Ніякої зарплати там не було - один одному допомагали. Андрієві збудували хату, Андрій собі заготовляє вже інший матеріал, там, наприклад, для підлоги чи верх зробити, а тим часом Василь щось вже підготував. От Васильови йдем разом зробим. От таким способом, такою толокою (ГТВ).

В нас був період - ні за шо не говорили, тільки за стройку. Зараз за шо говорять - тільки за гроші. Цеглу складали толокою, мурували толокою, крили, в основному, толокою (РНА).

Ви знаєте, село - гуртом! Оце будують хату - толоки. Кожний день толоки, через день толоки! Люди - все село сходиться, мажуть хати, помагають одне одному, бо іначе ж не виживеш (ГПА). 
В приведенных фрагментах доминирует положительная динамика повествования, передающая оптимистичный настрой сюжетов о совместной работе, положительные ощущения, которые помогали людям в достаточно сжатые сроки и в условиях дефицита строительных материалов все же построить жилье для всех переселенцев. Для этого использовано перечислительные конструкции, нанизывания глаголов (,село сходиться”, „мажуть хати”, „помагають одне одному”), противопоставление (,не так, як зараз”), неполные предложения, парцелляция („Наприклад, на цій вулиці - толокою. Збиралися”).

Наиболее трагические сюжеты-п ерен ос, потеря могил, кладбищ . Во время полевой работы даже было зафиксировано причитание по утраченным могилами, которые не удалось перенести:

Поринаєте, потопаєте,

А нас проклинаєте, шо не забрали.

Каже:

Ти лежиш, моя ненько,

Поринаєш, ненько...

А вона не змогла взяти?

Не могли. Там і вивозили, но не багато брали з нашого села. В нас село бідне було (ЯАП).

Исчезнувшие в результате затопления могилы и кладбища - обширная тема, требующая специального исследования. Особый трагизм ситуации обусловлен общеславянским верованием о строгом запрете нарушать покой умерших. А здесь приходилось не только нарушать этотпокой, но и осознавать, что всех покойников не удастся перенести, что они останутся под водой. Этот момент был очень болезненным, поскольку, по народным верованиям, плохим знаком было, когда вода просачивалась в свежевыкопанную могильную яму. Это плохо свидетельствовало о новопреставленном. Апри затоплении все древние могилы уходили под воду. Более того, со временем вода размывала старые захоронения, берега и люди видели гробы, кости бывших захоронений. Об этом всегда вспоминают с болью и горечью:

Цвинтарі переносили - викопували. В нас були гробокопателі з Нової Каховки. Ото вириють, позабирають кості, а те все назад. А тоді, як пустили воду в сентябрі - та всі ж труни пішли ж туди, у плотіну. Та там баграми їх витягали, бо забило. А які такі - недовго, то переселяли трунами, возили. Осюди - Озера. Коло Світловодська, Озера. Озера і Калова Балка. Там два села - попереселялися наші кладовища. А хто недавно похований - то у гробах возили (МАФ).

Переселили - сидять в степу тепер. Я кажу, що Дніпро зимою впадає, у фарватер уходить, а тут остаються, там де села були, - пісок. І оце я на- 
ходив, шо кладовище... Людей перенесли... В одном місці найшов, шо труни прямо лежять. Воно замулене. Ну а шо - кажен рік змиває пісок і труни пооставалися (ПИМ).

Принудительное п ер е с ле н и е вследствие затопления люди часто с т а в т в один ряд с другими трагедиями XX века, сравнивают масштабы своей трагедии с иными, часто худшими историческими событиями:

Наша жизнь - як велика трагедія. В мене мати була з І90о года, а батько 3 [І90]7-го году. В І7-ім годі була революція в [19]22-ім годі була голодовка... [І9]33-ій год - голодовка, 38-ий год - була іжовщина, забирали всіх комуністів, активістів і страчували. Потім в сорок первім годі - война, у [19]56-ім началася перестройка. Прийшли, хату обміряли[...]. Люди, канєшно, душевно переживали: хата стоїть, усе гарне - розбий, розрівняй, розвали і зрівняй із долівкою (КАФ).

Це один із злочинів компартії, не менший, чим голодомори, репресії. Затоплення (ЮАЯ).

Этот же прием характерен для рассказов украинских переселенцев так называемой операции „Висла”, которые сравнивали свое выселение и посадку в поезд со сюжетами Холокоста (подробно об этом см. Коваль-Фучило 20I8). Приведенные примеры сравнений - распространенный способ повысить уровень собственного пережитого горя, придать ему более высокий статус, усилить внимание слушателей.

Постоянным мотивом воспоминаний о переселении недавно стали р а с с к аз ы о встречах переселенцев одной деревни, бывших односельчан:

Пару років назад було 30 років, як переселення було. То тут в долині вони, самі люди зібралися, приглашали тих людей, котрі були по других селах [...]. То їм і музика грала, і столи гарні такі. Потому, вже після столу, бо я була тоди, після столу приплив той корабль, великий такий. I там жінки повбиралися в сорочки вишиті, сіли на той корабель, і він зробив круг. Набрали квіток багато і кидали ті квітки так, де хто жив. Співали пісні (ДТА).

Перший раз ми в парку зустрілися. Там є два столи такі великі, там в шашки грають, в шахмати. Ми там розіклалися, з музикою: гармошка, бубон. I то було якраз на Зелені свята?

Да, на Зелену неділю. Сиділи, згадували, плакали, співали, танцювали. А скільки людей прийило?

Тоді десь десятків три. В нас в цьому году, навєрно, було більше трьох десятків людей (РВМ). 
Ми ото г6-ий рік будем зустрічатись. Зустрічаємся ми на вокзалі. 3’їжджаються односельці. Хто приїхав - тут на вокзалі зустріли, заказуємо автобус і їдем на берег моря. Там у нас єсть місце, де ми зустрічаємося. Там накриваєм столи, варим юшку і все остальне (ГСІ).

Такое же характерно для письменных воспоминаний переселенцев, написанных по просьбе составителей:

Тепер щороку в першу суботу серпня, якнайближче до дня св. Іллі, імені якого був приход у селі, підсіняни зустрічаються на рибальському стані біля Дніпра. На жаль, корінних підсінян з кожним роком стає все менше, але приїжджають їхні діти, онуки. Ми спілкуємося, згадуємо рідне Підсінне, його жителів, які відійшли у вічність, і завжди починаємо зустріч з улюбленої пісні про Дніпро, яка стала гімном затопленого села (Михняк, Зубер 2019: 354).

С начала 2000-х годов в Украине происходят процессы, направленные на привлечение внимания общества к фактам ликвидации сел, потери плодородных земель, исторической памяти о древних поселениях, их культуре и самобытности. Сегодня эти процессы, являющиеся составными мемориальной культуры, бытуют в таких наиболее распространенных формах: коммеморативные практики (ежегодные или периодические встречи бывших жителей затопленных сел, выставки фотографий и печатных изданий о затопленных селах) архивирование и консервация данных о затопленных населенных пунктах (издание книг, посвященных этим селам, установление мемориальных знаков (досок, крестов, часовен) о прежних селах, попытка организовать музей затопленных сел и т.д.); популяризация информации и деятельности переселенческих обществ (например, общественная организация „Старый Днепр”) в средствах массовой информации.

Определить несказанные, нерассказанные, умалчиваемые сюжеты из истории переселения - дело нелегкое. Оно нуждается в хорошей осведомленности о материале, учете фактора автоцензуры, влияния личного опыта на рассказ о прошлом. Исследователи устного народного творчества, устной истории единодушны минимум в двух ключевых утверждениях о воспоминаниях людей. Вопервых, воспоминания проходят каждый раз через новый автопросмотр, авторедактирование, автоцензуру, переоценку. То, что человек расскажет о себе сегодня, будет в той или иной степени отличаться от рассказа через десять, двадцать лет. Во-вторых, на содержание автопрезентации влияют общественные процессы, которые происходят в конкретное время. Эти две характеристики воспоминаний - изменчивость и зависимость от исторических обстоятельств -отражены в рассказах о переселении жителей затопленных сел вследствие строительства искусственных водохранилищ и ГЭС. Так, сегодня происходит пересмотр, новое толкование событий, которые во время советской эпохи трактовали как победу над природой, над Днепром. И очевидцы переселения, и его непосредственные участники сегодня уже почти не говорят о достижениях, а задумываются о по- 
терях. Самым распространенным ответом на вопрос о том, как люди пережили переселение, является обобщенное утверждение, что было очень трудно:

Нелегко було. Ми, як переселялися, то й плакали, і хату обнімали, старики казали... в нас же піски там були, бугри, казали, шо „де вони води возьмуть", а воно і води набралося, і затопили все. Ширина водохранилища 40 кілометрів (МАФ).

\section{Дуже тяжело.}

Плакали?

Ну аякже! Оце ж переселили: приїхали, оце ж тобі шо? I пожилі були, шо не було нікого (БАТ).

Внимательный взгляд на опыт переселения дает основания говорить о б о пре деленных дости жения и получении нового опыта. Так, понятно, что в масштабах страны и в контексте современных поисков альтернативных источников энергии затопление является потерей чистой проточной воды, сельскохозяйственных земель, лесных угодий, важных исторических территорий. В то же время многие люди получили возможность значительно улучшить свои жилищные условия, поскольку переселенцам были выделены определенные денежные компенсации и предоставлены земельные участки в селах, где строились школы, больницы, прокладывались дороги. Об этом люди говорят очень мало, а то и вовсе ничего. Чем это обусловлено?

Работа над материалом позволяет определить такие факторы, влияющие на табуированность или промолвленность определенной темы в воспоминаниях: стратегия самопрезентации; актуальная пропаганда и дозволенность или запрещенность темы в обществе; личный и исторический опыт. Среди наших респондентов совсем немного людей, не более трех, оценили переселения положительно. Это те люди, которые избрали стратегию презентации победителя, а не жертвы: „Ну, в цей час... Як для мене... Тоді в селах не було ніде свєту. Потім будівництво Кременцуцької ГЕС, водосховища... [...]. I то він появився після переселення. А то не було в нас, і люди привикли до лампи, І2-ий номер - була така. »I2-ий рік« - по-народному” (МИЛ). Главным маркером для конструирования картины переселения для рассказчика становится появление электрического света, точнее замена керосиновой лампы электрической лампочкой. Целесообразность принудительного переселения обосновывается именно бытовыми удобствами, появившимися благодаря электричеству:

Як там історія складалася, я не знаю, як там хто, но це переселення дало цивілізацію, і велику. I зроблено правильно. Хоть там хто не каже, шо затоплено багато, бо було там багато природніх сінокосів, шо воно дало плюс - то тут люди хоть побачили освітлення. А мати моя казала: „Нашо той свєт?” - у нас було дві лампи І2-их. А тоді, як включили те, то й утюжок появився, те появилось, плитка появилась, та й електроплитка, 
холодільничок появився. Воно, звичайно, дало великі плюси. Людей 3 тих боліт, з тих комарів трохи відселили. Так як ото на Західній Україні затопе, там живуть люди, то я не щитаю, шо там дуже добре. А тут у нас землі гарні. Ставки кругом. Дереза, байбарис ще кажуть на неї, кущова така рослина. Дички груші, а культурної рослини там нема: вона застуджувалася, вимерзала і пропадала [...]. Але це переселення - воно дало прогрес людям (МИЛ).

Для аргументации собственной позиции рассказчик использует такие безапелляционные утвердительные конструкции: „...это переселение дало цивилизацию, и большую”; „И сделано правильно”; „Оно, конечно, дало большие плюсы”. Категоричность и умышленное понижение регистра четко прослеживается в утверждениях о затопленной территории: „Людей с тех болот, с тех комаров немного отселили". Напротив, при описании нового места жительства характерна завышенная оценка, ощутимая идеализация: „А здесь у нас земли хорошие. Ставки кругом". В целом на протяжении интервью избранная стратегия рассказчика выдержана до конца. Для его рассказа характерны штампы советской пропаганды того времени: „дало прогресс”, „государственной важности строительство”, „государство давало компенсации”, „людям стало лучше” и др.; все трудные моменты переселения описаныу прощенно.

Еще один интересный пример самопрезентации - это рассказ женщины, признавшей, что в свое время для ее только что созданной семьи ситуация переселения способствовала строительству собственного жилья, поэтому и строительство для нее не было сложным, ведь и государство помогало, и люди, и новое место для нее лучше, потому что не подтапливалось весной, и новое село было перспективным: „Ми переселилися сюди, там Дністер підбув; всьо забирали, ше й дерево на дрова, всьо позабирали. Там і за дерево якось платили, непогано. А як строїлися, то виписували кірпіч, матеріал, шифр, всьо то дешевше. То легко було строїтися"(ЛФЛ). В то же время в ее рассказе о родном селе ощущается ностальгия и горечь потери: „В нас село було маленьке, 56 хат всього. Дуже буле таке, як одна сім'я. Сниться, шо в школу там ходю, школа там в нас була, лиш чотири класи. Всьо було, хоть село маленьке, але всьо було" (ЛФЛ). В приведенных фрагментах показательным является употребление активных форм глагола: „переселилися”, „забирали”, „строїлися”, в отличие от распространенных в воспоминаниях пассивных конструкций: „людей переселили/вигнали/висилали". Активные формы свидетельствуют о добровольном сознательном выбоpe, а пассивные - о принудительности, вынужденных действиях рассказчика.

$$
* * *
$$

Воспоминания людей о прошлом на протяжении их жизни подвергаются многочисленным изменениям, переоценке, переосмыслению. Какие-то составляющие образа определенного события теряют актуальность, а какие-то человек начинает воспринимать и толковать по-другому. Временная дистанция позволяет 
рассказчику осмыслить прожитое, выбрать ракурс видения того или иного события. Так, строительство ГЭС на Днепре и Днестре, которое длительное время на официальном уровне оценивалось только положительно, сегодня проходит через переоценку и переосмысление. Записи воспоминаний в форме интервью с участниками переселения дают возможность выделить темы, мотивы, сюжеты, о которых говорят в первую очередь, много, с удовольствием, и те темы, о которых говорят неохотно, а то и вообще молчат. Среди любимых тем - идеализация потерянного места, сложности в результате строительства нового жилья, акцент на потере земли, села, общины, кладбища. Новой популярной темой в воспоминаниях стали рассказы о встречах переселенцев, продолжающихся с начала 2000-х годов. Мало проговореными темами является осмысление достижений вследствие переселения, недооценка полученного опыта. Набор тем в каждом интервью зависит от выбранной стратегии автопрезентации. Так, чаще всего наши рассказчики представляют свое переселение как потерю и поражение, потому затопленное село предстает в образе потерянного рая, а о новых возможностях, которые возникли после переселения, люди говорят мало и неохотно. Ракурс видения и оценки переселения зависит и от возраста респондентов. Так, самым трудным это событие было для людей старшего возраста, которые собственноручн обыли вынуждены разрушать свой дом, строиться на новом месте, привыкать к новым условиям. В рассказах людей, которые во время переселения были детьми, акценты несколько смещены, среди их любимых тем рассказы о встречах бывших односельчан, размышления о целесообразности ГЭС, экологический ущерб в результате этого строительства.

\section{ПЕРЕЧЕНЬ ИНФОРМАНТОВ}

БВИ - Бугаенко Василий Иванович, I94I г.р., переселенец, род. в ныне несуществующем с. Пенькивка Новоегоровского р-на Кировоградской обл., с г959 г. живет в с. Пидгирне Кременчугского р-на Полтавской обл., запись 19.05.20I2.

БАТ - Бережной Андрей Петрович, І950 г.р., переселенец, род. в ныне несуществующем с. Морозивка Глобинского р-на Полтавской обл., запись в с. Новоселовка Кременчугского р-на Полтавской обл., 19.05.20I2.

ГПА - Гич Петр Архипович, I94I г.р., переселенец, род. в ныне несуществующем с. Пидсиння Переяслав-Хмельницкого р-на Киевской обл., запись в г. Переяслав 21.06.2019.

ГСИ - Гич София Игоревна, 1947 г.р., переселенека род. в ныне несуществующем с. Пидсиння Переяслав-Хмельницкого р-на Киевской обл., запись в г. Переяслав 21.06.2019.

ГТВ - Горбняк Тарас Васильевич, 1945 г.р., переселенец, высшее образование, род. в ныне несуществующем с. Бакота Каменец-Подольского р-на Хмельницкой обл., запись в с. Гораивка Каменец-Подольского р-на І8.07.20I4.

ДМС - Дубенюк Мария Сергеевна, I932 г.р., переселенка, род. в г. Херсон, жила в ныне несуществующем с. Бакота Каменец-Подольского р-на Хмельницкой обл., запись в с. Гораивка Каменец-Подольского р-на 21.07.20I4. 
ДТА - Дубенюк Татьяна Александровна, І957 г.р. переселенка, род. в ныне несуществующем с. Бакота Каменец-Подольского р-на Хмельницкой обл., запись в с. Гораивка КаменецПодольского р-на 21.07.2014.

ЖНИ - Жменько Надежда Ильинична, г96о г.р. род. в частично переселенном с. Скородистик (бывший Ирклиевский р-н, Полтавская обл.), высшее образование, запись в с. Скородистик Чернобаевского р-на Черкасской обл. 29.07.20I4.

ЗВФ - Загреба Валентина Федоровна, І950 г.р., род. в частично переселенном с. Скородистик (бывший Ирклиевский р-н, Полтавская обл.), колхозница, запись в с. Скородистик Чернобаевского р-на Черкасской обл. ог.08.20I4.

КАФ - Каменская Анастасия Федоровна, І932 г.р., переселенка, род. в ныне несуществующем с. Жовнино Градижского р-на Полтавской обл., с I959 г. живет в с. Пидгирне Кременчугского р-на Полтавской обл., запись г9.05.2012.

КЛГ - Кикоть Лариса Григоровна, І970 г.р., род. в с. Канивци Чернобаевского р-н Черкасской обл., запись в с. Скородистик Чернобаевского р-на 03.08.20I4.

ЛПА - Левченко Параска Алексеевна, I940 г.р., колхозница, переселенка, род. в с. Кручанив, жила в ныне несуществующем с. Бакота Каменец-Подольского р-на Хмельницкой обл, запись в с. Гораивка Каменец-Подольского р-на I9.07.20I4.

ЛФЛ - Литвинюк Федора Лаврентьевна, г942 г.р., переселенка, род. в ныне несуществующем с. Надднистрянка Каменец-Подольского р-на Хмельницкой обл., запись в с. Гораивка КаменецПодольского р-на І8.07.20I4.

МАФ - Мотайло Антонина Федоровна, І937 г.р н., переселенка, род. в ныне несуществующем с. Калабарок Новоегоровского р-на, запись в с. Григорьевка Светловодского р-на Кировоградской обл. І9.05.2012.

МИЛ - Манько Иван Лукович, I948 г.р., переселенец, род. в частично переселенном с. Скородистик (бывший Ирклиевский р-н, Полтавская обл.), высшее образование, запись в с. Скородистик Чернобаевского р-на Черкасской обл. 3І.07.20I4.

НАГ - Никуляк Александр Григорьевич, 1926 г.р., переселенец, род. в ныне несуществующем с. Кониловка Каменец-Подольского р-на Хмельницкой обл., бухгалтер, запись в с. Гораивка Каменец-Подольского р-на I8.07.20I4.

ОЕП - Онищенко Евдокия Петровна, г928 г.р., переселенка, род. в частично переселенном с. Скородистик (бывший Ирклиевский р-н, Полтавская обл.), колхозница, запись в с. Скородистик Чернобаевского р-на Черкасской обл. ог.08.20I4.

ПИМ - Поиздник Иван Михайлович, 1959 г.р., род. в с. Хрущивка Золотоношского р-на Черкасской обл., инженер, запись в с. Скородистик Чернобаевского р-на Черкасской обл. 29.07.20I4.

РВМ - Ревега Василий Никитич, 945 г.р., род. в ныне несуществующем с. Комаривка ПереяславХмельницкого р-на Киевской обл., запись в г. Переяслав 20.06.2019.

РНА - Рыбак Надежда Андреевна, І962 г.р., переселенка, колхозница, род. в ныне несуществующем с. Бакота Каменец-Подольского р-на Хмельницкой обл, запись в с. Гораивка КаменецПодольского р-на 26.07.20I4.

ЧЕА - Чепинога Екатерина Андреевна, І93І г.р., род. в частично переселенном с. Скородистик (бывший Ирклиевский р-н, Полтавская обл.), колхозница, запись в с. Скородистик Чернобаевского р-на Черкасской обл. 29.08.20I4.

ЧМЛ - Чепинога Михаил Логвинович, І929 г.р., председатель сельсовета, учитель, директор школы, род. в частично переселенном с. Скородистик (бывший Ирклиевский р-н, Полтавская обл.), запись в с. Скородистик Чернобаевского р-на Черкасской обл. I9.08.20I4.

ЮНС - Юхно Нина Семеновна, І952 г.р., переселенка, род. в частично переселенном с. Скородистик (бывший Ирклиевский р-н, Полтавская обл.), запись в с. Скородистик Чернобаевского р-на Черкасской обл. ог.08.20I4.

ЮАЯ - Юхно Александр Яковлевич, І963 г.р., род. в г. Ирклиев, образование высшее, запись в с. Скородистик Чернобаевского р-на Черкасской обл. 02.08.20I4.

ЯАП - Якуба Анна Павловна, І926 г. н., переселенка, род. в с. Ялынци Градижского р-на, с г96о г. живет в с. Билецкивка Кременчугского р-на Полтавской обл., запись Марины Куренной 20.05.20I2. 
ЯКИ - Ярошевская Екатерина Ивановна, І956 г.р., переселенка, род. в ныне несуществующем

с. Бакота Каменец-Подольского р-на Хмельницкой обл, запись в с. Гораивка КаменецПодольского р-на 2І.07.20I4.

\section{БИБЛИОГРАФИЯ}

Горбняк, Т. (2004). Бакота. Затоплена доля. Хмельницький: Поділля.

Горбняк,Т. (2018). Стежками Бакоти. Кам’янець-Подільський: Аксіома.

Горбняк, Т. (2020). Абетка бакотянина. Кам’янець-Подільський: Аксіома.

Горбовий, О. (20I5). Проблема Дніпрових порогів та Дніпрогес (I927-I932). Стратегія адаптації. Наукові записки з украӥнської історії, 37, 95-Іо2.

Горбовий, О. (2016). Проблема Дніпрових порогів та Дніпрогес (г920-г970-ті рр.). Стратегія трансформації. Гілея, I07, 54-57.

Горбовий, О. (2020). Комплексна трансформація украӥнського Придніпров'я у контексті гідроенергетичного освоєння Дніпра (кін. ХІХ cm. - I980-ті pp.)[автореферат диссертации кандидата исторических наук]. Переяслав.

Гук, Б. (ред.) (І997). Пропам’ятна книга І947. Варшава: Тирса.

Іващенко, В. (20I7). Створення музею затоплених сіл Канівського водосховища [интернет-страница „Старий Дніпро”]. Режим доступа: http://olddnieper.org.ua/news/item/95-stvorennia-muzeiuzatoplenykh-sil-pereiaslavshchyny. Дата обращения: 09.ІІ.2020.

Коваль-Фучило, І. (ред.) (20I2). Голосіння. Київ: ІМФЕ НАН України.

Коваль-Фучило, I. (20I6). Концепт дому в оповідях про примусове переселення. W: B. Halczak (red.), Łemkowie, Bojkowie, Rusini. Historia, współczesność, kultura materialna i duchowa. T. 6 (s. I47-I58). Słupsk-Warszawa: Tyrsa.

Коваль-Фучило, I. (20I8). Пам’ять про Голокост у спогадах українців - переселенців операції „Вісла”. Слов'янський світ, I7, 92-Іо2.

Коваль-Фучило, I. (2020а). Пам'ять про затоплення. Творчість Довженка і усні наративи. Народознавчі зошити, I56(6), I445-I453. doi: https://doi.org/IO.I5407/nz2020.06.I445

Коваль-Фучило, И. (2020b). Утраченное место в воспоминаниях о принудительном переселении и в социальных практиках. Фолклористика. Часопис Удружења фолклориста Србије, 5(I), 73-88. doi: https://doi.org/IO.I8485/folk.2020.5.I.3

Кузьменко-Лісовенко, К. (2018). Затоплена Придніпровська цุивілізація. Історія. Людські долі. Київ: „Інтерконтиненталь-Україна”.

Лесик, М. (2007). Циблі-моє рідне село на Переяславщчині (Спогади). Переяслав-Хмельницький: СКД.

Михняк, М. (ред.) (20I8). Затоплений рай. Андруші у спогадах та документах. Київ: Український пріоритет.

Михняк, М. (2020). Були над Дніпром Трахтемирів і Монастирок. Документи, спогади, світлини. Київ: Український пріоритет.

Михняк, М., Зубер, С. (20г9). Нам Підсінне тепер тільки сниться. Село у спогадах та документах. Київ: Український пріоритет.

Сорокова, С. (2015). Не летять ластівки у Зарубинці. Історико-краєзнавчий нарис. ПереяславХмельницький: ФОП Лукашевич О. М.

Шевчук, Т. (2009). „Дике поле” історії і „чисте поле” фольклору. Українські думи в історичному та міфологічному вимірах. Матеріали до української етнологіï, 8, 206-2ІІ.

Godyń, M. (20I5). Opowieść o utraconej wsi Maniowy. Studium z antropologii pamięci. Kraków: Polska Akademia Umiejętności.

Hajduk-Nijakowska, J. (2020). Badanie opowieści wspomnieniowych o tragedii żydowskiej w czasie II wojny światowej. Literatura Ludowa, 64(2), 35-49. 
Halicka, B. (20I5). Polski Dziki Zachód. Przymusowe migracje i kulturowe oswajanie Nadodrza I945-I948. Kraków: Universitas.

Prymaka-Oniszk, A. (20I7). Bieżeństwo I9I5. Zapomniani uchodźcy. Wołowiec: Wydawnictwo Czarne. Wylegała, A. (20I4). Przesiedlenia a pamięć. Studium (nie)pamięci społecznej na przykładzie ukraińskiej Galicji i polskich „Ziem Odzyskanych”. Toruń: Wydawnictwo Naukowe UMK. 